\title{
Strategies of Translating Chinese Address Terms into English in Teaching
}

\author{
Bin Chen \\ School of Foreign Languages \\ Wuhan Institute of Technology \\ Wuhan, Hubei province, China \\ E-mail: apple163@163.com
}

\author{
Shiyu Peng \\ School of Foreign Languages \\ Wuhan Institute of Technology \\ Wuhan, Hubei province, China
}

\author{
Wenyan Mao \\ School of Foreign Languages \\ Wuhan Institute of Technology \\ Wuhan, Hubei province, China
}

\begin{abstract}
Due to cultural differences, Chinese address terms are more complicated than English address terms, and the number of Chinese address terms are much more than English address terms. It is hard to find equivalent English address terms for some Chinese address terms with unique Chinese culture in translation. The present author discussed four pieces of strategies of translating Chinese address terms into English in teaching, and called for college English teachers to guide their students to understand cultural differences between Chinese and English address terms and to use the strategies in translating Chinese address terms into English.
\end{abstract}

Keywords-Chinese address terms; English address terms; cultural differences; strategies for translation

\section{INTRODUCTION}

The objective of College English teaching is to develop students' ability to use English in an all-round way [1], including listening, speaking, reading, writing and translating. Because Chinese address terms are more complicated than English address terms, and the number of Chinese address terms are much more than English address terms, students usually get confused in translating Chinese address terms into English address terms. It is hard for them to find an equivalent address term in English for some Chinese address terms with unique Chinese culture. In order to solve the problem, it is necessary to probe the strategies of translating Chinese address terms into English for English teaching.

\section{LITERATURE REVIEW}

Translation is a complicated activity. Richards says that translation is likely to be the most complex thing (Richards, 1953:247) [2]. For translation itself has abundant connotation and denotation. The definition of translation varies according to different translation theory. Newmark claims that translation is rendering the meaning of a text into another language in the way the author intended the text (Newmark, 1991:5) [3]. Obviously, Newmark defines translation from the angle of the source language writer. Nida thinks that translating consists in reproducing in the receptor language the closet natural equivalent of the source language message, first in terms of meaning and secondly in term of style (Nida,1982:80) [4]. Transparently, Nida's definition stresses equivalence in meaning and similarity in style. Because the address terms are combination of symbol, meaning and culture, and its prominent function is to start a communication. So translating Chinese address term into English is actually the transformation between two language symbols.

Although there are different types of address terms according to different literature, kinship address terms and social address terms is the most popular classification. Kinship address terms are usually applied to address those who are related to the relatives by blood or marriage. Social address terms are used to address the non-relatives. Being applied frequently in daily communications, kinship and social address terms are definitely a significant and indispensable part of social life [5]. It is acknowledged that extended-family was the traditional typical family model in China in the past. Even now, the phenomenon that three or four generations live under the same roof is quite common in Chinese rural areas. The number of Chinese kinship address terms is nearly 90, and each Chinese address term only represents one type of relationship. In western societies, nuclear family is the typical family mode, and most children are supposed to live on their own after 18 years old. So the number of kinship address in western society is much smaller, which in turn lead to the polysemy and vagueness of address terms. For instance, "aunt", "uncle", "cousin", "nephew", "niece" are all terms that represent more than one type of relationship. Generally speaking, social address terms can be classified into general terms, name terms, zero terms, title terms, and occupational terms and so on [6]. From the perspective of sentiment color or attitude, both kinship address terms and social address terms can be classified into abasing terms, haughty terms, honorific terms, endearing 
terms, abusive terms, etc.. Different address terms demonstrate the social distance and the relationship between the communicators. Failing to use the appropriate address terms is a violation to the politeness principle of communication, which will definitely affect the smoothness of the communication. Undoubtedly, in order to help students to translate properly Chinese address terms into English, College English teachers are suppose to instruct the strategies of translating Chinese address terms into English.

\section{STRATEGIES OF TRANSLATING ChINESE ADDRESS TERMS INTO ENGLISH}

Both Chinese and English address terms contain certain cultural meaning. Because of cultural differences, many Chinese address terms have no completely equivalent address term in English. College English teachers may instruct students to use the following strategies to translate Chinese address terms into English.

\section{A. Translating Chinese Kinship Address Terms into English with Methods of Extension and Omission According to Cultural Differences}

Chinese kinship address terms symbolize the difference of paternal and maternal line. People can easily differentiate relatives of paternal line from that of maternal line by kingship address terms. For example, "Zu Fu" (grandfather) is the kinship address term for father's father, "Wai $\mathrm{Zu} \mathrm{Fu"}$ (grandfather) is the kinship address term for mother's father. While there is no difference between paternal and maternal line in English kinship address terms, western people use "grandfather" for both father's and mother's father. English kinship address term "aunt" is used to address father's and mother's sisters, the wife of father's and mother's brother. If students want to differentiate these kinship address terms, they can translate them into "aunt xxx (given name)", and the same to "uncle", "cousin", "nephew" and "niece".

Another notable distinction between Chinese and English kinship address terms is that Chinese kinship address terms of the same generation differ seniors from juniors, such as "Da Ge"(the first elder brother), "Er Ge"(the second elder brother), "San Ge"(the third elder brother), "Bo Bo"(father's elder brother), "Shu Shu"(father's younger brother) etc., while there is a blank in English address terms, western people use "elder or younger brother xxx (given name)" to show the difference, and the same to "sister", "uncle", "cousin", "nephew" and "niece". If students want to differentiate these kinship address terms, they can translate them into "elder or younger brother xxx (given name)", and the same to other Chinese kinship address terms of the same generation in translation.

In order to improve students' ability to translate properly Chinese kinship address term into English, College English teachers are supposed to develop students' cross-cultural knowledge about kinship address terms. In western society, people are accustomed to addressing each other by name, it is quite common to hear a person of a younger generation addresses another person of an older generation by name, even among family members. It is a symbol of endearment, intimate and equal friendship for a boy to address his parents or grandparents by name, even some other informal address terms like "guys", "fellow" and so on.

So College English teachers may instruct students the cultural differences between Chinese kinship address terms and English kinship address terms, and guide them to learn to translate Chinese kinship address terms into English with methods of extension and omission according to cultural differences.

\section{B. Translating Chinese Social Address Terms into English with Context Clue by Differing Taboos, Self-Abasing , Titles etc.}

Chinese taboo emerged very early. Before Qin Dynasty, the word "Zhen" can be used as first person pronoun "Wo" in Chinese (It means "I" in English.). Since it came to Qin Dynasty, "Zhen" became a word limited to emperors. With the development of the feudal society, the scope of taboo extended larger and larger, not only "national taboos" but also "family taboo" began to emerge in history.

Chinese self-abasing address system is complicated and highly developed. Chinese usually use honorific terms and self- abasing terms in pairs, honorific term is used to address the other person of a communication and self-abasing term is used to address the speaker himself. Traditional Chinese honorific terms are "Xian Sheng", "Lao Ye", "Lao Ban" etc. Traditional Chinese self-abasing terms are "Bi Ren", "Bu Cai", "Zai Xia" and so on. For Chinese has the tradition to be moderate and honor the old. There are also honorific terms in English such as "Your honor" and "Your majesty", but the self-abasing terms in English are exiguous. In western culture, the word "old" means one is weak and losing energy and creativity. Being young, energetic, powerful and capable are valued in western society. People use "He" to represent God and "I" to himself all the time. Almost all the Chinese official titles, occupational titles and professional titles can be used as address terms. The regular formula is "family name + title". For instance, "Li Buzhang" (Minister Li), "Liu Jingli" (Manager Liu), "Wu Kuaiji” (Accountant Wu) and so on. In western culture, only a few English address terms, like "president", "priest", "nun", "doctor" and "professor" can be used in this way, such as President Obama, Father Lawrence, Doctor White, and Professor Miller etc.. People are accustomed to address each other by name except among strangers. It is natural for an employee or a young man addresses his employer, senior, professor directly by name.

So College English teachers are supposed to instruct students the custom of English social address terms, and guide students to analyze Chinese taboos, self-abasing, titles etc. in the context clue[7], then properly translate them into English.

\section{Translating Chinese Address Terms into English by Selecting Semantic Equivalents}

Although there are so many differences between Chinese and English address terms, there are, in both Chinese and English, some address terms that possess equivalent cultural meaning, communication values and context styles. So it is 
convenient to choose the equivalents in translating this kind of Chinese address terms into English. For instance, Chinese address terms "Ba", "Mu Qin" can be directly translated into "dad", "mother" respectively. So college English teachers might instruct students to select semantic equivalents as their first strategy in translating Chinese address terms into English.

\section{Translating Chinese Address Terms into English by Analyzing Their Meaning in Pragmatics}

In order to properly translate Chinese address terms in literature into English, the relationship, status, tone and the possible meaning of the interlocutor in pragmatics should be explicitly figure out by analyzing the context, only by this way, can the equivalently translated form in pragmatics can not be found. For example, there is Chinese address "Jia $\mathrm{Mu}$ " in A Dream of the Red Mansion. By pragmatic meaning, the translated address term "the Lady Dowager" is better than the literal translation "Grandmother Jia" [8]. According to the plot in A Dream of the Red Mansion, "Jia Mu" is the senior who gets the highest honor at Rongguo Mansion, and she is a genuine "matriarch". So college English teachers are supposed to instruct students to learn to select equivalents in pragmatics in translating Chinese address terms in literature into English.

\section{CONCLUSION}

Chinese address terms are complicated and changing with time, and they contain abundantly unique Chinese culture. Due to cultural differences, college students often feel confused when they translate Chinese address terms into English. In order to solve the problem students meet in translating Chinese address terms into English, Firstly, College English teachers are supposed to introduce cultural differences between two address term systems to their students so that their students' cross-cultural awareness is fostered. Secondly, College English teachers might instruct their students the strategies of translating Chinese address terms into English. Thirdly, College English teachers may give brief introduction to the meaning of some Chinese address terms in semantics and pragmatics to their students so that their students can learn to analyze Chinese address terms with context clue.

\section{REFERENCES}

[1] Gaodeng jiaoyusi, College English Curriculum Requirements, Shanghai, China: Shanghai foreign language education press, 2007, pp. 25-26.

[2] Richards I. R. Towards a Theory of Translating: In Studies in Chinese Thought, Beijing, China: Foreign Language Teaching and Research Press, 1953, pp.247.

[3] Newmark P. A Textbook of Translation, Shanghai, China: Shanghai Foreign Language Education Press, 1991, pp.5.

[4] Nida E A. The Theory and Practice of Transaltion , Beijing, China: Foreign Language Teaching and Research Press, 1982, pp.80.

[5] Baker H. D. R. Chinese Family and Kinship, New York: Columbia University Press, 1979, pp.49-64.
[6] Jucker H. A. \& Taavitsainen, Diachronic Perspectives on Address Terms Systems, Amsterdam/Philadelplia: John Benjamins Publishing Company, 2002, pp.159-164.

[7] Nida. E. A. Language and Culture: Context in Translating, Shanghai, China: Shanghai Foreign Language Education Press, 2001, pp.82-120.

[8] Versuchen. Jef. Understanding Pragmatics, Beijing, China: Foreign Language Teaching and Research Press, 2000, pp.156-200. 